Ya.V. SHKORBOTUN

\title{
MAXILLARY SINUS CYST AS A RISK FACTOR FOR OSTEOMEATAL COMPLEX BLOCK
}

\author{
Scientifical department of miniinvasive surgery (head of department-prof. I.V. Boiko) \\ State Institution of Science «Research and Practical Center of Preventive \\ and Clinical Medicine» State Administration Department \\ Department of Otorhinolaryngology (head of department - prof. V.O. Shkorbotun) \\ National University of Healthcare named after P.L. Shupyk
}

According to various authors, cysts of the maxillary sinuses are diagnosed in 7.5$15.6 \%$ of the population $[1,5,15]$ and the share of sinusotomies for this pathology among ENT profile operations is $4.1 \%$ [6]. These statistics are largely related to the improvement of diagnostic capabilities and the development in modern conditions of minimally invasive endoscopic technologies for surgery of the nasal cavity and paranasal sinuses.

$97 \%$ of cysts detected by computed tomography and magnetic resonance imaging have an asymptomatic course and are regarded as a diagnostic "finding" [2, 14], which does not always mean the need to remove it.

The main criteria for removal of a cyst of the maxillary sinus at present are its large size and recurrent or persistent sinusitis, the development of which may be associated with the presence of a cyst [1,9]. A very important criterion for removing the cyst is a local or general headache, discomfort in the area of the sinus projection, the feeling of its expansion, and nasal breathing disorders. These symptoms are not completely specific to the cyst, but excluding other causes of its occurrence, they can be a strong argument in favor of surgery $[2,9]$.

Taking into account literature data and the subjectivity of the criterion for determining the size of the cyst (large / small) we decided to express these terms in metric units and to study the effect of cyst size on the likelihood of natural sinus drainage and sinusitis.

Patients who are scheduled for dental implantation of the upper jaw should be considered separately. A cyst is a risk factor for post-implantation complications of these people, especially with subantral bone augmentation. The most common complication is perforation of the mucoperiosteum with the exit of osteogenic material into the lumen of the sinus. A cyst in the maxillary sinus in such patients increases the risk of the mucoperiosteum rupture during sinuslift due to the tension of the cyst wall during its elevation in the alveolar recessus, and therefore potentially affects the effectiveness of dental implantation. Similar complications occur in 3-20\% of implanted patients according to dates of various authors $[7,10,12]$.

Thus, the question of studying the effect of cyst size on the drainage function of the maxillary sinus depending on its size remains an acute problem for both otorhinolaryngology and maxillofacial surgery.

The purpose of the study was to clarify the indications for surgical treatment of maxillary sinus cysts as a risk factor for sinus drainage disorders in the development of maxillary sinusitis.

\section{Material and methods}

We analyzed the condition of the maxillary sinuses on computed tomography (CT) of 57 patients who were examined and treated at State Scientific Institution "Scientific and Practical Center for Preventive and Clinical Medicine" of the State Administration. The average age of the patients was $38.1 \pm 1.4$ (from 20 to 57 years old). There were 32 men (56.1\%) and 25 women (43.9\%) among them. 
Depending on the diagnosis, the patients were divided into three groups. The first group included 20 people with bilateral maxillary sinusitis in acute rhinosinusitis (40 sinuses); the second group comprised 22 patients after unilateral subantral augmentation of the maxilla, complicated by acute maxillary sinusitis (22 sinuses). The control group had 15 almost healthy patients (30 sinuses). CT for patients with acute rhinosinusitis (group 1) was performed in case of insufficient effectiveness of drug treatment or to avoid complications. The second group patients were prescribed $\mathrm{CT}$ according to the protocol for determining the state of the sinus after bone augmentation. The control group patients underwent CT because of other reasons which were not connected with the nasal cavity and sinuses.

The criterion for exclusion from the second group was non-compact (disseminated) placement of osteoplastic material in the area of augmentation of the upper jaw bone, which indicated the loss of the mucoperiosteum barrier function or the used sealing membrane.

Taking into account the unilateral and bilateral process, we analyzed the examination results of 57 people (92 sinuses). The formed groups of patients were representative by age and sex.

X-ray examination of patients was performed using cone-beam computed tomography i-CAT Gendex CB-500 and Brilliance16 Philips using the program for visualization of DICOM images RadiAnt DICOM Viewer by CLOSE algorithm [8].

Metric studies were performed on a coronary CT scan at the ostiomeatal level, and the most probable site of bone augmentation, which usually corresponds to the level of placement of 5-6 teeth [11]. It is in this area of the alveolar recessus that the condition of the mucoperiosteum has a decisive influence on the probability of developing local complications.

To determine the possibility of blocking the ostiomeatal complex (OMC) with a cyst, we performed the following measurements (Fig. 1): h0 is basic distance from the bottom of the maxillary sinus to the upper limit of the maxillary sinus ostium; h1 is the height of mucoperiosteum elevation above the level of the bone of the alveolar recessus; $\mathrm{h} 2$ is the height of mucosal edema during post-augmentation sinusitis (distance from the upper level of osteogenic masses to the upper limit of the mucous membrane above this area); $\mathrm{h} 3$ is the magnitude of mucosal edema in acute rhinosinusitis (distance from the cortical plate of the bone in the upper parts of the OMC to the surface of the swollen mucosa) and h4 is the height of the free lumen of the maxillary sinus (distance from the surface of the alveolar mucosa to the mucosal surface).

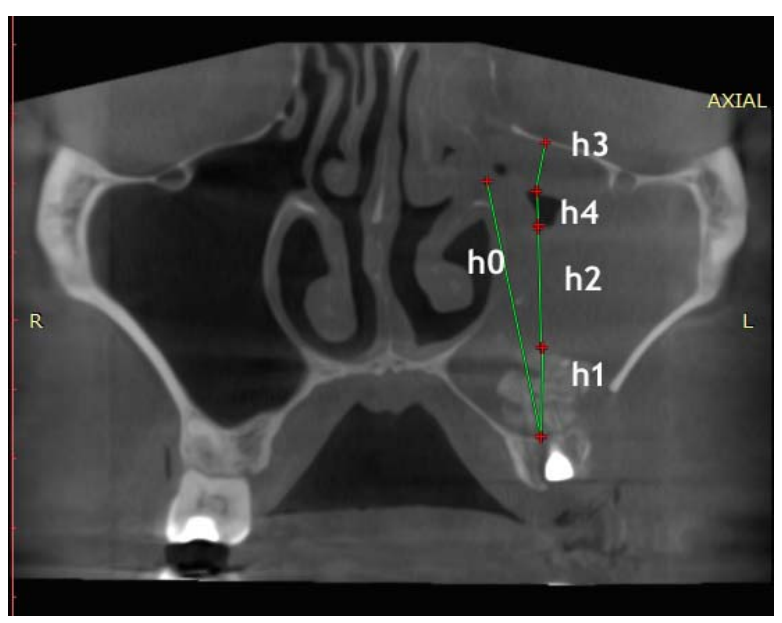

Figure 1. CT of the upper jaw in the coronary projection of a patient with sinusitis after sinus lift.

Note: h0 - total height of maxillary sinus, h1 magnitude of mucoperiosteum elevation, h2 - height of mucoperiosteum thickening of alveolar recessus, $h 3$ - thickening of mucous membrane in the area of maxillary sinus ostium, h4 - height of the free lumen of the maxillary sinus in a patient with sinusitis after subantral bone augmentation

These measurements were based on the judgment that the block of the sinus ostium was possible when the upper edge of the cyst was in contact with the surface of the mucous membrane of the upper parts of the maxillary sinus ostium. Displacement of the cyst was possible due to the development of mucoperiosteum edema in rhinosinusitis and augmentation of the bone of the alveolar recessus of the upper jaw. Thus, we studied the level of mucoperiosteum thickening and its displacement during sinus lift.

Thus, the distance from the upper edge of the inflamed mucosa of the alveolar recessus to the level of the mucosa in the OMC area determines the approximate height of the cyst, which can lead to the OMC block. The poten- 
tial "blocked" cyst size was calculated by the ourselves created formula:

$$
H(\text { cyst })=h 0-(h 1+h 2+h 3),
$$

Where:

$\mathrm{h} 0$ is the distance from the cortical layer of the alveolar recessus bone to the upper border of the maxillary sinus ostium;

h1 is elevation height due to sinus lift of the mucoperiosteum of the alveolar recessus of the maxillary sinus;

$\mathrm{h} 2$ is the thickness of the mucous membrane of the alveolar recessus;

$\mathrm{h} 3$ is the thickness of the mucous membrane in the OMC area;

note-all distances are measured by $\mathrm{CT}$ scans on the coronary section at the level of the maxillary sinus ostium.

Statistical processing of the results obtained during the study was carried out using the statistical analysis package IBM SPSS Statistics Trial (without violating the terms of the license). The obtained data were processed by the methods of variation statistics with the calculation of statistical significance (reliability) of differences between control groups and study groups. We also used the methods of parametric (Student's t test) and nonparametric statistical analysis (Chi-Square Test). 95\% confidence interval (CI) was calculated by the Wilson method with continuity correction [3]. The diagram was formed by using Microsoft Office Excel-2013 (license N 62248259).

\section{Results and discussion}

There are several reasons for the displacement of a cyst located in the alveolar recessus with a possible OMC block in patients after sinus lift and dental implantation: 1) displacement due to elevation of the mucoperiosteum to the introduction of osteogenic material; 2) displacement due to the development of reactive inflammatory process after bone augmentation; 3) displacement due to the development of post-augmentation sinusitis; 4) displacement due to the development of acute rhinogenic rhinosinusitis in the postoperative period. It should be noted that in this case it is important not only the displacement of the cyst but also the swelling of the mucous membrane in the area of the OMC ostium, which increases the chances of occlusion of the natural drainage path.

The examples of measuring the parameters of metric studies of the structures of the maxillary sinus are shown in Fig. 2, 3.

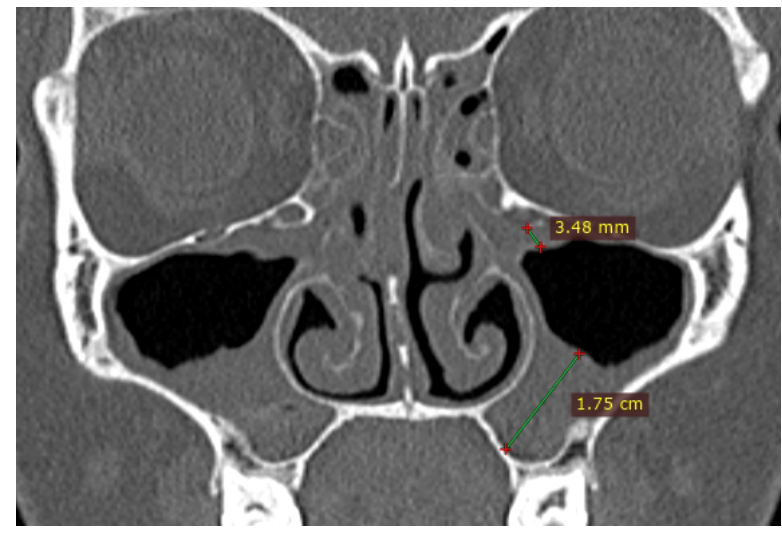

Figure 2. Example of measuring the thickening of the mucoperiosteum of the alveolar recessus (17.5 $\mathrm{mm})$ and the area of the ostiomeatal complex (3.48 $\mathrm{mm}$ ) in a patient with acute rhinosinusitis.

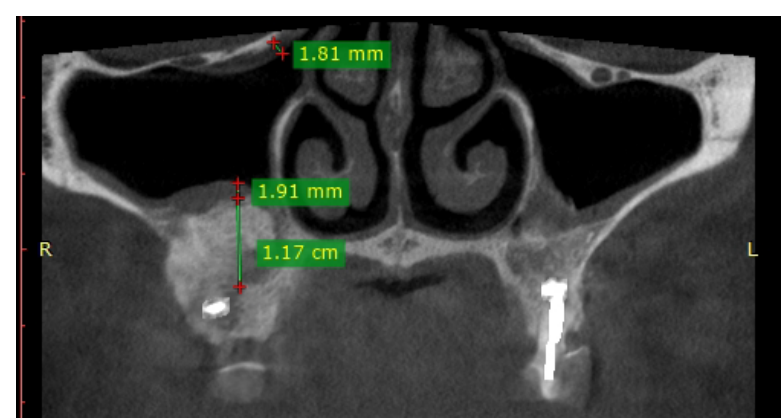

Figure 3. Example of measuring the height of mucoperiosteum elevation in a patient after sinus lift due to augmentation of the maxilla $(11.7 \mathrm{~mm})$, the height of the reactive thickening of the mucoperiosteum $(1.9 \mathrm{~mm})$ and the thickening of the mucous membrane in the ostium of the maxillary sinus $(1.81$ $\mathrm{mm})$.

Indicators for measuring structures of maxillary sinus of patients in groups are presented in table 1.

Table 1 shows that the average distance from the bottom of the alveolar recessus to the ostium of the maxillary sinus in patients who were scheduled for augmentation of the maxilla was $34.4 \pm 0.7 \mathrm{~mm}$, and was significantly greater than in patients of other groups. Such a big difference in the height of the sinus can be explained by resorption over time of the bone of the alveolar process of the upper jaw in the area of the adentia. Thickening of the mucope- 
riosteum of the alveolar recessus was observed both in the group $1(9.1 \pm 0.5 \mathrm{~mm})$ and 2 $(7.9 \pm 0.7 \mathrm{~mm})$. These indicators are significantly different compared to those in the control group $0.7 \pm 0.2\left(\mathrm{p}_{1-3}, 2-3,<0.05\right)$. At the same time, a significant increase in the thickness of the mucoperiosteum in the OMC area was observed only in patients with acute rhinosinusitis $(4.9 \pm 0.3 \mathrm{~mm})$. The identified changes reflect the pathogenetic features of the thickening development in the mucoperiosteum layer of the maxillary sinus in the odontogenic and post-traumatic nature of its inflammation. Thus, in group 1 patients (rhinogenic sinusitis) almost all sinus walls were involved in the inflammatory process with a predominance of edema in the alveolar recessus, and a mucoperiosteum reaction of group 2 patients was observed directly in the area of injury or around the causative teeth.

Table 1

The results of morphometry of the maxillary sinuses structures in patients of study and control groups

\begin{tabular}{|c|c|c|c|}
\hline \multirow[b]{2}{*}{ Indicators } & \multicolumn{3}{|c|}{ Comparison groups, $\mathrm{N}-$ number of sinuses (patients) } \\
\hline & $\begin{array}{l}\text { Group } 1 \text { - acute rhino- } \\
\text { genic rhinosinusitis } \\
\mathrm{N}=40(20)\end{array}$ & $\begin{array}{c}\text { Group } 2-\text { acute } \\
\text { post-augmentation upper } \\
\text { jaw of sinusitis } \\
\mathrm{N}=22(22)\end{array}$ & $\begin{array}{l}\text { Control group } \\
\mathrm{N}=30(15)\end{array}$ \\
\hline $\begin{array}{l}\text { Distance h0 } \\
\text { (cortical plate of alveolar recessus - } \\
\text { the upper limit of the ostium) } \\
\mathrm{M} \pm \mathrm{m}\end{array}$ & $31.3 \pm 0.5^{*}$ & $34.4 \pm 0.7 * *$ & $31.1 \pm 0.6$ \\
\hline $\begin{array}{l}\text { Distance h1 } \\
\text { (elevation height of the periosteal } \\
\text { layer of mucoperiosteum of the } \\
\text { alveolar recessus), } \mathrm{M} \pm \mathrm{m}\end{array}$ & 0 & $10.5 \pm 0.4$ & 0 \\
\hline $\begin{array}{l}\text { Distance h2 } \\
\text { (thickness of mucoperiosteum } \\
\text { of the alveolar recessus), } \mathrm{M} \pm \mathrm{m}\end{array}$ & $7.9 \pm 0.3$ & $9.1 \pm 0.5 * *$ & $1.9 \pm 0.3 * * *$ \\
\hline $\begin{array}{l}\text { Distance h3 } \\
\text { (thickness of mucoperiosteum } \\
\text { in the OMC area), } \mathrm{M} \pm \mathrm{m}\end{array}$ & $4.9 \pm 0.3 *$ & $0.8 \pm 0.3$ & $0.7 \pm 0.2 * * *$ \\
\hline $\begin{array}{l}\text { Distance } \mathrm{h} 4 \\
\text { (the amount of free lumen of the } \\
\text { maxillary sinus), } \mathrm{M} \pm \mathrm{m}\end{array}$ & $21.2 \pm 0.8^{*}$ & $14.7 \pm 1.1 * *$ & $28.5 \pm 0.7 * * *$ \\
\hline
\end{tabular}

Note: Significance of differences ${ }^{*} \mathrm{p}_{1-2}<0.05 ;{ }^{* *} \mathrm{p}_{2-3}<0.05 ;{ }^{* * *}{ }_{-} \mathrm{p}_{1-3}<0.05$.

Elevation of the periosteal layer of mucoperiosteum was observed only in patients who underwent augmentation of the alveolar process of the upper jaw (group 2) and its displacement at the OMC level was $10.5 \pm 0.4$ $\mathrm{mm}$ (distance from the cortical plate of the alveolar process to the upper limit of osteogenic mass).

The potentially most dangerous cysts located in the alveolar recessus in terms of risk of developing OMC block are those that are at the shortest distance from it, i.e. directly below it. In order to clarify the indications for surgical treatment of cysts of the maxillary sinus, we calculated the size of the cysts, which can potentially lead to OMC block in the case of displacement of the cyst by a swollen mucous membrane during the development of sinusitis.

The study took into account the peculiarities of changes in the mucous membrane of the maxillary sinus inherent in different variants of sinusitis. Thus, there is swelling of the entire mucous membrane of the sinus, i.e. both in the alveolar recessus and in the area of the ostiomeatal complex in acute rhinosinusitis. In reactive sinusitis after dental implantation and sinus lift the mucous membrane of the OMC 
area is not changed and in the area of the alveolar recessus there occurs increase both due to edema of the mucoperiosteum and to the introduction of osteogenic material under the mucoperiosteum.

The size of the potential "blocked" cyst the distance from the upper edge of the inflamed mucosa of the alveolar recessus to the level of the mucosa in the OMC area, was calculated by the formula presented above.

In the course of research we obtained the following data: the total value of the decrease in the height of the maxillary sinus lumen at the OMC level was $12.8 \pm 0.5 \mathrm{~mm}$ and $20.4 \pm 0.8$ $\mathrm{mm}$ in group 1 and 2, respectively. The estimated maximum size of the cyst, which does not threaten the block of ostium in patients without inflammation in the sinus in the absence of elevation of the Schneider membrane and tissue edema is $28.5 \mathrm{~mm}$; in rhinogenic sinusitis, when there is swelling of the mucous membrane in the areas of the alveolar recessus and $\mathrm{OMC}$ it is $18.5 \mathrm{~mm}$; in postimplantation sinusitis with bone augmentation (mucoperiosteum edema and sinus floor elevation) it is 14.0 $\mathrm{mm}$, and in the case of postimplantation sinusitis without sinus lift it is $24.5 \mathrm{~mm}$.

The results of measuring the height of the free lumen of the maxillary sinus (h4), which is the distance from the surface of the mucous membrane of the alveolar recessus to the surface of the mucous membrane in the upper edge of the maxillary sinus ostium, are presented at Fig. 4.

Comparing the data presented in the diagram 1 we note that the average actual indicators of the distance from the surface of the mucous membrane of the alveolar recessus of the sinus to the surface of the mucous membrane in the upper parts of the ostium differ from the estimated by $12.6 \%$. The confidence interval of $95 \%$ of the fluctuations of the data obtained during the measurements for group 1 patients was $17.4-23.7 \mathrm{~mm}$, for group 2 it was 12.2-19.9 mm, for control group it was 25.5 $29.5 \mathrm{~mm}$. Therefore, considering the fact that edema in postimplantation sinusitis in patients with sinus lift will reduce the height of the sinus lumen at the level of OMC to $12.2 \mathrm{~mm}$, and in acute rhinosinusitis - up to $17.4 \mathrm{~mm}$, we can assume that the cyst, which size exceeds these dimensions, can potentially lead to the development of a block of the natural opening of the maxillary sinus. For convenience, it is advisable to round the size of the cyst, which can potentially lead to impaired drainage of the maxillary sinus with the development of postaugmentation sinusitis to $15 \mathrm{~mm}$, and rhinogenic sinusitis - up to $20 \mathrm{~mm}$. If the cysts are larger than the mentioned ones, it is advisable to recommend their planned surgical removal.

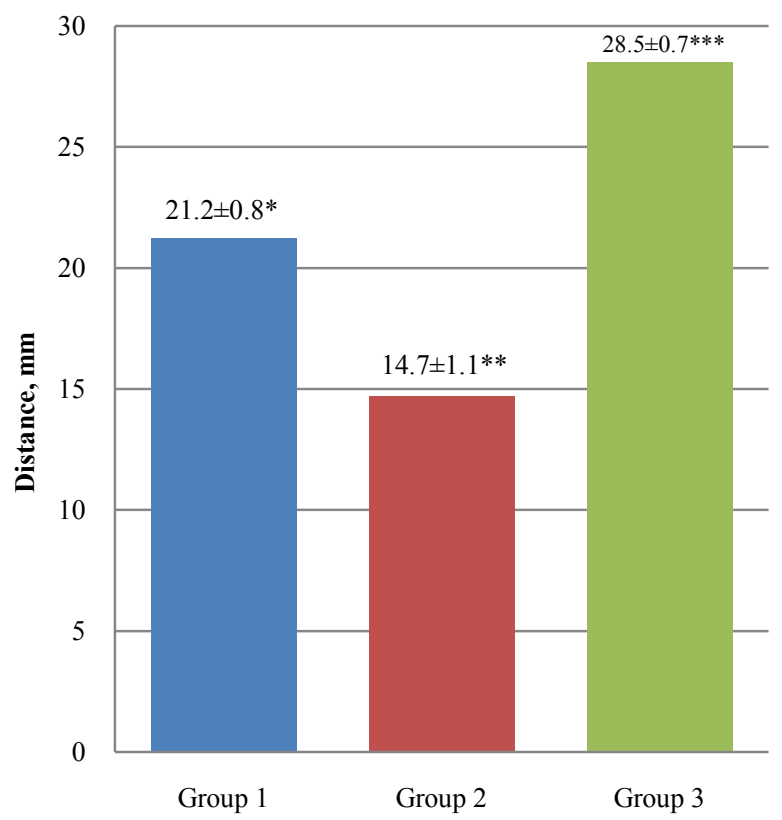

Fig. 4. The average distance from the surface of the mucous membrane of the alveolar recessus of the maxillary sinus to the surface of the mucous membrane of the upper edge of the ostium in patients of study and control groups.

Note: $* \mathrm{p}_{1-2}<0.05, * * \mathrm{p}_{1-3}<0.05, * * * \mathrm{p}_{2-3}<0.05$;

The obtained data on the anatomical features of the maxillary sinus and its changes due to subantral augmentation and adentia confirm the results published by other authors [7, 13]. It should be noted that the most authors stated block of the maxillary sinuses as more significant factor for development of complications after subantral augmentation than the rupture of the mucoperiosteum of the alveolar recessus $[7,12]$.

The result of the investigation is creation the metric criteria (size of cyst and distance to OMC) for surgical removing of the maxillary sinuses cysts considering the possibility of ostiomeatal complex block after subantral augmentation. The sinus sizes can vary signifi- 
cantly. It was found that the height of the maxillary sinus depends on gender (the sinuses are larger in men), age, and the incidence of adentia $[11,12]$.

S. Torretta et al. (2011) regarded the distance from the top of the cyst to the ostiomeatal complex as the most significant and more prognostically valuable criterion for determining the risk of sinus block but they do not specify the value of "critical" distance in which surgical treatment indicated [12].

Therefore, it will be more practical to focus on sinus space above the cyst as the indication for surgery. In case of its value, which exceeds the average data on the probable size of the sinus lumen in rhinosinusitis in persons with augmentation of the maxilla (12.8 \pm 0.5 $\mathrm{mm})$ and without it $(20.4 \pm 0.8 \mathrm{~mm})$ should performed the surgical treatment.

\section{Conclusion}

1. To assess the potential of the ostiomeatal complex block by a cyst located in the alveolar recessus in acute rhinosinusitis, its vertical size is important according to coronary sections of computer tomography at the ostiomeatal complex level, which usually corresponds to the most probable sinus lift and the level of 5-6 teeth of the upper jaw.

2 . With the development of acute rhinosinusitis, the distance from the surface of the mucous membrane of the alveolar recessus to the upper border of the maxillary sinus ostium decreases due to mucoperiosteum edema by an average of $12.8 \pm 0.5 \mathrm{~mm}$, and with sinusitis after sinus lift, taking into account the height of bone augmentation tissues it decreases by 20.4 $\pm 0.8 \mathrm{~mm}$.

3 . If the vertical size of the cyst of the alveolar recessus of the maxillary sinus according to coronary computer tomography at the ostiomeatal complex level is more than $20 \mathrm{~mm}$, and more than $15 \mathrm{~mm}$ for patients with planned sinus lift, there are indications for its removal, as it may worsen the course of acute rhinosinusitis due to the anastomosis block.

Compliance with Ethics Requirements: The author declare no conflict of interest regarding the article.

\section{References}

1. Bal M, Salturk Z, Bal GC, Berkiten G, Atar Y, Sünnetçi G. Mucous Retention Cysts in the Paranasal Sinuses: A Retrospective Study Otolaryngology Online Journal. 2016;6(2):109. Available from: https://www.alliedacademies.org/articles/ mucous-retention-cysts-in-the-paranasal-sinuses-aretrospective-study.html.

2. Gonçales ES, Gonçales AG, Lima ES, Rocha JF, Noleto JW, Hochuli-Vieira E. Symptomatic mucous retention cysts of the maxillary sinus: Case report. Rev Sul Bras Odontol. 2015;12:233-7. Available from: http://revodonto.bvsalud.org/scielo.php?script =sci arttext\&pid=S1984-56852015000200015\#back.

3. Grjibovski AM, Ivanov SV. Gorbatova MA. [Descriptive statistics using statistica and spss software]. Nauka I Zdravoohranenie. 2016;1. Available from: https://cyberleninka.ru/article/n/opisatelnayastatistika-s-ispolzovaniem-paketov-statisticheskihprogramm-statistica-i-spss. [In Russian].

4. Hankyeol K, Eun Kyu Lee, Hyo Yeol Kim, SangDuck Hong, Hun-Jong Dhong, Seung-Kyu Chung, MD A Case of Symptomatic Maxillary Retention
Cyst. Journal Rhinology. 2018;25(1):59-62. DOI: https://doi.org/10.18787/jr.2018.25.1.59.

5. Haaga JR, Boll D. Computer Tomography \& Magnetic Resonance Imaging of The Whole Body. Elsevier Health Sciences, 2016. P. 2904. DOI: https://doi.org/10.1002/jmri.1880050206.

6. Kryukov AI, Tsarapkin GY, Zayratyants OV, Tovmasyan AS, Fedotkina KM, ArtemyevaKarelova AV, Panasov SA. [The strategy of the of surgical treatment of the cysts in the maxillary sinus]. Vestn Otorinolaringol. 2019;84(1):42-5. DOI: https://doi:10.17116/otorino20198401142. [In Russian].

7. Lee IH, Kim DH, Kim SW, Park JB, Kim SW. An Anatomic Study on the Maxillary Sinus Mucosal Thickness and the Distance between the Maxillary Sinus Ostium and Sinus Floor for the Maxillary Sinus Augmentation. Medicina (Kaunas, Lithuania). 2020;56(9):470. DOI: https://doi.org/10.3390/ medicina56090470.

8. O'Brien WT Sr, Hamelin S, Weitzel EK. The Preoperative Sinus CT: Avoiding a "CLOSE" Call 
with Surgical Complications.] Radiology. 2016;281(1):10-21. DOI: https://doi:10.1148/ radiol.2016152230.

9. Omezli M, Torul D, Cankaya S. Frequency and characteristics of retention cysts in the maxillary sinus in a Turkish patient population. J. Stomat. Occ. Med. 2015;8:17-21. DOI: https://doi.org/ 10.1007/s12548-015-0120-z.

10. Piotrovich AV., Latyushina LS. [Analysing the structure and frequency complication of indirect sinuslift with single-stepdental implantation]. Modern problems of science and education. 2016;1. Available from: http://www.scienceeducation.ru/ru/article/view?id=24062. [In Russian].

11. Shkorbotun YaV. [X-ray Features of the Mucoperiastole of the Alveolar Bay of the Maxillary Sinus, as a Risk Factor for Developing Intraoperative Complications in Subantral Bone Augmentation]. Ukrajins'kyj zhurnal medytsini, biologii ta sportu. 2018;1(3);199-205. DOI: https://doi.org/10.26693/ jmbs03.01.199. [In Ukrainian].
12. Torretta S, Mantovani M, Testori T, Cappadona M, Pignataro L. Importance of ENT assessment in stratifying candidates for sinus floor elevation: a prospective clinical study. Clin Oral Implants Res. 2013;24;Suppl A:100:57-62. DOI: https://doi.org/ 10.1111/j.1600-0501.2011.02371.x.

13. Wagner F, Dvorak G, Nemec S, Pietschmann P, Traxler H, Schicho K, Seemann R. Morphometric analysis of sinus depth in the posterior maxilla and proposal of a novel classification. Sci Rep. 2017;7:45397. DOI: https://doi.org/10.1038/ srep45397.

14. Weber RK, Hosemann W. Comprehensive review on endonasal endoscopic sinus surgery. GMS Curr Top Otorhinolaryngol Head Neck Surg. 2015;14:Doc08. DOI: https://doi:10.3205/ cto000123.

15. Xiao J1, Chen J1, Wang Y2 Balloon catheter dilation technology combined with a fibrolaryngoscope to treat a maxillary sinuscyst. Eur Arch Otorhinolaryngol. 2016;273(2):407-11. DOI: https://doi:10.1007/s00405-015-3588-7.

Надійшла до редакції 27.09.21

(C) Ya.V. Shkorbotun, 2021

\title{
MAXILLARY SINUS CYST AS A RISK FACTOR FOR OSTEOMEATAL COMPLEX BLOCK
}

\author{
Shkorbotun $\mathrm{YaV}$ \\ State Institution of Science «Research and Practical Center of Preventive and Clinical Medicine» \\ State Administration Department \\ National University of Helthcare named after P. L. Shupyk \\ Email:lorkiev@ukr.net
}

Abstract

Introduction: Cysts of the maxillary sinuses are found in about $10 \%$ of the population. There is a necessity to clarify indications for cyst removal taking into account its size.

The purpose of the study to clarify the indications for surgical treatment of maxillary sinus cysts as a risk factor for sinus drainage disorders in the development of maxillary sinusitis.

Methods and materials: 57 people (92 sinuses) were examined. There were 20 patients (40 sinuses) with acute rhinosinusitis, 22 patients (22 sinuses) with post-augmentation sinusitis, and 15 (30 sinuses) almost healthy individuals among them. Prediction of the cyst size, which can lead to blockage of the maxillary sinus ostium, was performed by direct measurement on coronary sections at the ostiomeatal complex level distance from the surface of the mucoperiosteum in the area of the alveolar recessus to the lower surface of the mucosal surface in the area of the ostium. The obtained data were verified by calculation method taking into account the height of the sinus at the level of the osteomeatal complex, the magnitude of possible mucoperiosteum edema in the alveolar recessus and ostium in acute rhinosinusitis and post-augmentation sinusitis, as well as the magnitude of mucoperiosteum elevation due to sinus lift.

Results: It was found that the vertical size of the cyst, which can potentially lead to blockage of the maxillary sinus ostium in acute rhinosinusitis is $21.2 \pm 0.8 \mathrm{~mm}, 14.7 \pm 1.1 \mathrm{~mm}$ in sinusitis after augmentation of the maxilla, and $28.5 \pm 0.7 \mathrm{~mm}$ in practically healthy individuals. The calculated values are $18.5 \mathrm{~mm}, 14.0 \mathrm{~mm}$ and 24.5 $\mathrm{mm}$, respectively. In case of acute rhinosinusitis, the distance from the apex of the cyst to the surface of the mucous membrane of the ostiomeatal complex area may decrease by $12.8 \mathrm{~mm}$, and in sinusitis after sinus lift it may decrease by $20.4 \mathrm{~mm}$. 
Conclusions: To assess the potential of the ostiomeatal complex block by a cyst located in the alveolar recessus in acute rhinosinusitis, its vertical size is really important according to coronary sections of at the ostiomeatal complex level corresponding to the location of 5-6 teeth of the upper jaw. The indication for removal of the cyst of the alveolar recessus of the maxillary sinus, as a factor that may worsen the course of acute rhinosinusitis due to the anastomosis block, is its size exceeding $20 \mathrm{~mm}$, and $15 \mathrm{~mm}$ for patients who plan to sinus lift.

Keywords: maxillary sinus cyst, ostium block, sinusitis, subantral bone augmentation, sinus lift, indications for surgical treatment.

\title{
КІСТА ВЕРХНЬОЩЕЛЕПНОГО СИНУСУ ЯК ФАКТОР РИЗИКУ БЛОКУ ОСТІОМЕАТАЛЬНОГО КОМПЛЕКСУ
}

\author{
Шкорботун ЯВ \\ Національна медична академія післядипломної освіти імені П.Л. Шупика \\ Державна наукова установа «Науково-практичний центр профілактичної та клінічної медицини» \\ Державного управління справами \\ Email:lorkiev@ukr.net \\ Анотаиія
}

Bcmyn: Кісти верхньощелепних синусів виявляються у близько 10\% населення. Покази до видалення кіст в залежності від розміру останніх потребують уточнення.

Метою дослідження було уточнити показання до хірургічного лікування кіст верхньещелепного синусу, як фактору ризику порушення дренування пазухи при розвитку верхньощелепного синуситу.

Методи і матеріали: Було обстежено 57 осіб (92 синуса). Серед них 20 пацієнтів (40 синусів) 3 гострим риносинуситом, 22 пацієнта (22 синуса) з постаугментаційним синуситом, та 15 - (30 синусів) практично здорових осіб. Прогнозування розміру кісти, яка може призводити до блокування остіуму верхньощелепного синуса виконувалась шляхом безпосереднього вимірювання на коронарних зрізах на рівні остіо-меатального комплексу, відстані від поверхні мукоперіосту в ділянціальвеолярної бухти до нижніх відділів поверхні слизової оболонки в ділянці остіуму. Отримані данні було перевірено розрахунковим методом із врахуванням висоти синуса на рівні остіомеатального комплексу, величини можливого набряку мукоперіосту ділянці альвеолярної бухти та остіуму при гострому риносинуситі та постаугментаційному синуситі, а також величини елевації мукоперіосту за рахунок синусліфтингу.

Отримані результати та їх обговорення: Встановлено, що вертикальний розмір кісти, яка потенційно може призводити до блокування остіуму верхньощелепного синусу при гострому риносинуситі

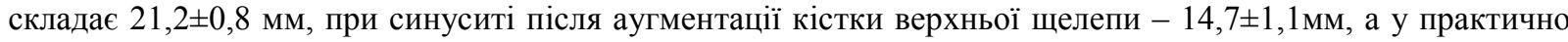
здорових осіб - 28,5 $\pm 0,7$ мм. Розрахункові значення відповідно складають 18,5; 14,0 та 24,5 мм. В разі розвитку гострого риносинуситу відстань від верхівки кісти до поверхні слизової оболонки ділянки остіомеатального комплексу може зменшитись на 12,8 мм, а при синуситі після синусліфтингу - на 20,4 мм.

Висновки: Для оцінки потенційної можливості блоку остіо-меатального комплексу кістою, що розміщена в альвеолярній бухті при гострому риносинуситі, має значення ії вертикальний розмір за даними коронарних зрізів комп'ютерної томографії на рівні остіо-меатального комплексу, що відповідає ділянці розміщення 5-6 зубів верхньої щелепи. Показанням до видалення кісти альвеолярної бухти верхньощелепного синусу, як фактору що може погіршувати перебіг гострого риносинуситу за рахунок блоку співустя $\epsilon$ перевищення іiї розміру 20 мм, а у пацієнтів, яким планується синусліфтинг 15 мм.

Ключові слова: кіста верхньощелепного синуса, блок остіуму, синусит, субантральна аугментація кістки, синусліфтинг, покази до хірургічного лікування. 